\title{
Carbamazepine Associated Prolonged Erection in a Patient with Bipolar Disorder
}

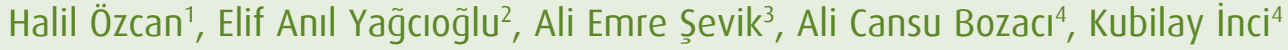

\section{ÖZET:}

iki uçlu bozukluk tanısı olan bir hastada karbamazepin kullanımı ile ilişkili uzamış ereksiyon

Karbamazepin iki uçlu bozuklug̃u olan hastalarda duygudurum düzenleyici olarak yaygın kullanılan bir antiepileptiktir. Karbamazepin nöronlarda dopamin, norepinefrin ve glutamik asit düzeylerini etkiler ve sodyum ve potasyum kanalları üzerinde etkisini gösterir. Karbamazepin dopamin salınımı ve döngüsünü artııı ve farklı beyin bölgelerindeki monoamin düzeylerinde deg̃ișikliklere neden olur. Uzamış ereksiyon ve priapizmin ortaya çıkış mekanizması korpus kavernosum $\alpha 1$ adrenerjik blokajı olarak bilinmekte olup; karbamazepinin adrenerjik reseptörler üzerindeki etkisine dair bilgiler çok sınırlıdır. Sonuç olarak karbamazepin tedavisi alan hastalarda uzamış ereksiyon riskini tespit etmek ve uzamıs ereksiyon ile karbamazepin arasındaki ilişkiyi araştırmak için yapılacak çalıșmalar gereklidir.

Anahtar sözcükler: karbamazepin, uzamış ereksiyon, iki uçlu bozukluk

Journal of Mood Disorders 2012;2(3):126-8

\section{ABSTRACT:}

Carbamazepine associated prolonged erection in a patient with bipolar disorder

Carbamazepine is an anticonvulsant and is extensively used in patients with bipolar disorder as a mood stabilizer. Although carbamazepine affects dopamine, norepinephrine, and glutamic acid levels in neurons, it mainly shows its effect on sodium and potassium channels. Carbamazepine enhances dopamine release and turnover and leads to differential alterations of monoamine levels in discrete brain regions. The mechanism of the emergence of prolonged erection and priapism is related to $\alpha 1$ adrenergic blockage in corpus cavernosum, however the knowledge about the effects of carbamazepine on adrenergic receptors is very limited. Therefore, further studies are necessary to identify the risk for prolonged erection in patients treated with carbamazepine and to investigate the relationship between prolonged erection and carbamazepine.

Key words: carbamazepine, prolonged erection, bipolar disorder

Journal of Mood Disorders 2012;2(3):126-8
${ }^{1} M$.D., Department of Psychiatry, Dr. Zekai Tahir Burak Women Health Education and Research Hospital, Ankara-Turkey ${ }^{2}$ M.D., Hacettepe University Hospital Psychiatry Department, Ankara-Turkey ${ }^{3}$ M.D., Medikar Hospital Psychiatry Department, Karabük-Turkey ${ }^{4}$ M.D., Hacettepe University Hospital Urology Department, Ankara-Turkey

Yazısma Adresi / Address reprint requests to: Halil Özcan, M.D., Department of Psychiatry, Dr. Zekai Tahir Burak Women Health Education and Research Hospital, Ankara-Turkey

Telefon / Phone: +90-312-306-5389

Faks / Fax: +90-312-312-4931

Elektronik posta adresi / E-mail address: drhalilozcan@gmail.com

Kabul tarihi / Date of acceptance: 11 Haziran 2012/ June 11, 2012

\section{Bag̃ıntı beyanı:}

H.Ö., E.A.Y., A.E.Ş., A.C.B., K.I.:. Yazarlar bu makale ile ilgili olarak herhangi bir çıkar çatıșması bildirmemiștir.

Decloration of interest: H.Ö., E.A.Y., A.E.S., A.C.B., K.I.: The authors reported no conflict of interest related to this article.

\section{INTRODUCTION}

Prolonged erection is a persistent, usually painful erection of the penis with or without sexual stimulation or desire continuing for minutes or hours. Prolonged erection is an antecedent of priapism. Many medical conditions and drugs including psychotropic agents may cause prolonged erection and priapism (1). The mechanism of the emergence of prolonged erection and priapism related to psychotropic drugs is not exactly known, but it has been attributed to their $\alpha 1$ - adrenergic receptor blockade in corpus cavernosum. Priapism is classified as ischemic and non-ischemic. In ischemic priapism cavernous old blood is drained by a butterfly needle or diluted solution of alpha-adrenergic agonist is given into the corporal space. If medical treatment fails, surgical intervention may be needed. The goal is to prevent fibrosis and impotence due to tissue death. For this reason, a fistula between the deep dorsal vein or saphenous vein and the glans penis, corpus cavernosum, and corpus spongiosum is created to open a new route for the venous return (2). Perineal trauma history , ongoing or intermittent painless erections indicates a nonischemic priapism. Conservative treatment can be followed. In the early period local ice and pressure could be applied to the penis, selective angiographic embolization may be needed in some cases. If the procedure fails, open surgical ligation may be attempted 
(3). Trazodone is the most common psychotropic agent associated with prolonged erection and priapism; however, the patients taking some other antidepressants (sertraline, paroxetine), mood stabilizers, and antipsychotics (quetiapine, risperidone, olanzapine, etc.) may experience priapism, as well (4). As an extensively used anticonvulsant, major side effects of carbamazepine include dry mouth, constipation, dizziness, headache, thrombocytopenia, and liver toxicity. To the best of our knowledge, there are no published reports of prolonged erection associated with the use of carbamazepine. We report a case of prolonged erection while taking carbamazepine for the maintanence treatment of bipolar disorder.

\section{CASE REPORT}

Mr. T was a 65-year-old male, had a history of bipolar disorder. He was first diagnosed with bipolar disorder 31 years ago in 1979. He was treated with lithium carbonate for 24 years, then switched to carbamazepine because of impaired renal function due to lithium treatment. He had been receiving carbamazepine $400 \mathrm{mg} /$ day for seven years at the time of his first complaint regarding undesired prolonged erections. Carbamazepine serum level was measured as $6.2 \mu \mathrm{g} / \mathrm{ml}$ (therapeutic range $4-8 \mu \mathrm{g} / \mathrm{ml}$ ) at last follow up visit. His mental state examination was evaluated as normal. He reported that he experienced episodes of prolonged erections at nights during previous seven years. He had not mentioned this complaint earlier to any physician in previous follow up visits because he was embarassed. Each episode, lasting approximately 60 minutes, was sometimes painless and sometimes painfull but distressing to him. Due to the overlap of his complaint with the duration of carbamazepine use, we considered the possibility of prolonged erection being associated with this drug. Urology was consulted, urological examination revealed no abnormal sign. No further tests or work up were recommended by the Urology Department with these findings. Other probable causes (drugs such as antipsychotics, antihypertensives, perineal trauma, malignancies and etc.) were excluded by medical history and physical and urological examination. He did not report any other disease and drug usage. Blood pressure was 120/80 mm Hg and evaluated in normal ranges. Blood tests (occult blood test, serum electrolytes, glucose and cholesterol levels, liver and kidney function tests) revealed no abnormalities. Changing the drug regimen, if possible or a conservative approach with local ice and pressure application was recommended by the Urology Department. After consultation carbamazepine was discontinued and sodium valproate $1000 \mathrm{mg}$ daily was started as the new mood stabilizer with approval of the patient. At the follow-up visit one week later his mental state examination was normal and no side effects were reported. Serum valproate level was measured as 78 $\mu \mathrm{g} / \mathrm{ml}$ (therapeutic range $60-100 \mu \mathrm{g} / \mathrm{ml}$ ). The patient declared that he had not experienced any prolonged penile erections after the discontinuation of carbamazepine and initiation of sodium valproate treatment. At his follow up one month later, it was found out that he discontinued sodium valproate and restarted carbamazepine on his own. He stated that he felt himself uncomfortable and gained weight with sodium valproate. He had decided to get back to carbamazepine treatment despite prolonged penile erections, which seemed to be associated with it. He also reported that undesired penile erections reappeared after starting carbamazepine but he declared that he got used to take carbamazepine and he was okay with it. He did not report any other side effects of sodium valproate, but did not want to try it again. On follow up, the patient has still been taking carbamazepine and reporting prolonged erections. His psychiatric condition has been stable and he has refused other alternative treatment options for maintanence treatment of bipolar disorder.

\section{DISCUSSION}

Carbamazepine is extensively used in patients with bipolar disorder as a mood stabilizer (5). Although carbamazepine affects dopamine, norepinephrine, and glutamic acid levels in neurons, it mainly shows its effect on sodium and potassium channels (6). Knowledge about the effects of carbamazepine on adrenergic receptors is very limited, yet this case report of prolonged erections associated with carbamazepine suggests that it might have antiadrenergic effects (7). Carbamazepine enhances dopamine release and turnover and leads to differential alterations of monoamine levels in discrete brain regions (8). Carbamazepine increases prefrontal dopamine release via 5 HT1A receptor (9). It has been well known 
that dopamine receptor agonists have facilitatory effect on penile erection and sexual behavior $(10,11)$. A case report presenting priapism associated with oxcarbazepine (a derivative of carbamazepine) exists in the literature, but no previous report of such an association regarding carbamazepine could be found (12). In our patient the emergence of prolonged erection occurred with the use of carbamazepine, disappeared with its discontinuation, and reappeared upon being rechallenged with the drug. In literature penile color doppler ultrasonography is adviced as an imaging technic in prolonged erections and priapism (13). However we could not have a doppler ultrasonography of the patient due to erections occurring at night. The occurrence of prolonged erection in a patient with no other medical conditions or pharmacological interventions led us to conclude that carbamazepine is

\section{References:}

1. Sood S, James W, Bailon MJ. Priapism associated with atypical antipsychotic medications : a review. Int Clin Psychopharmacol 2008; 23: 9-17.

2. Mains E, Aboumarzouk O, Ahmad S, El-Mokadem I, Nabi G. A minimally invasive temporary cavernoso-saphenous shunt in the management of priapism after failed conservative treatment. Minim Invasive Ther Allied Technol. 2011 Dec 5. [Epub ahead of print]

3. Burnett AL. Surgical management of ischemic priapism. J Sex Med 2012; 9:114-120.

4. Rosenberg I, Aniskin D, Bernay L. Psychiatric treatment of patients predisposed to priapism induced by quetiapine, trazodone and risperidone: a case report. Gen Hosp Psychiatry 2009; 31: 98.

5. Singh V, Muzina DJ, Calabrese JR . Anticonvulsants in bipolar disorder. Psychiatr Clin N Am 2005; 28: 301-323.

6. Sitges M, Guarneros A, Nekrassov V. Effects of carbamazepine, phenytoin, valproic acid, oxcarbazepine, lamotrigine, topiramate and vinpocetine on the presynaptic $\mathrm{Ca}^{2+}$ channel-mediated release of $[3 \mathrm{H}]$ glutamate: comparison with the $\mathrm{Na}^{+}$channel-mediated release. Neuropharmacology 2007; 53: 854-862.

7. Post RM, Weiss SR, Chuang DM. Mechanisms of action of anticonvulsants in affective disorders: comparisons with lithium. J Clin Psychopharmacol 1992; 12: 23-35. associated with the appearance of this condition.

This case report suggests that clinicians should be aware of the possibility that carbamazepine might induce prolonged penile erections. Patients with painless prolonged erections may be less likely to contact their physicians or report this physical change as a complaint. Physicians should consider the risk and inquire about such a side effect in patients using carbamazepine. Urology should be consulted if necessary. Because of frequent use of carbamazepine in various medical conditions including mood disorders and impulse control disorders in psychiatry; epilepsy and neuropathic pain in neurology practice, this potential side effect warrants further investigation. Future research should aim to explore and clarify the mechanism and the frequency of prolonged erections associated with carbamazepine.

8. Elphick M. Effects of carbamazepine on dopamine function in rodents. Psychopharmacology (Berl) 1989; 99: 532-536.

9. Ichikawa J, Meltzer HY. Valproate and carbamazepine increase prefrontal dopamine release by 5 HT1-A receptor activation. Eur J Pharmacol 1999; 1: 1-3.

10. Argiolas A, Melis MR. Central control of penile erection: role of the paraventricular nucleus of the hypothalamus. Prog Neurobiol 2005; 76: 1-21.

11. Succu S, Sanna F, Melis T, Boi A, Argiolas A, Melis MR. Stimulation of dopamine receptors in the paraventricular nucleus of the hypothalamus of male rats induces penile erection and increases extra-cellular dopamine in the nucleus accumbens: Involvement of central oxytocin. Neuropharmacology 2007; 52: 1034-1043.

12. Negin B, Murphy TK. Priapism associated with oxcarbazepine, aripiprazole, and lithium. J Am Acad Child Adolesc Psychiatry 2005; 44: 1223-1224.

13. İlbey YÖ, Göktaş C, Kuvel M, Albayrak S. Perineal Travmaya Bağlı Nadir Bir Yüksek Akımlı Priapizm Olgusu. Kartal Eğitim ve Araştırma Hastanesi Tıp Dergisi 2002; 13: 46-47. 